\title{
Notes
}

\section{Multi-institutional Cooperation to Develop Digital Media for Interactive Greenhouse Education}

\author{
Milton E. Tignor ${ }^{1}$, Sandra B. Wilson ${ }^{2,6}$, Gene A. Giacomelli ${ }^{3}$, \\ Chieri Kubota $^{3}$, Efren Fitz-Rodriguez ${ }^{3}$, Tracy A. Irani ${ }^{4}$, \\ Emily B. Rhoades ${ }^{4}$, and Margaret J. McMahon ${ }^{5}$
}

AdDitional INDEX wORDs. active learning, digital repository, distance education, flash-based simulation, greenhouse production, impact assessment, instructional technology, web technology

$\mathrm{R}$ ussell (1999) compiled a large bibliography of research demonstrating that there is not a significant difference between standard and distance education learning. Yet rapid advances in the use of technology for the discipline of horticulture have been shown to improve student learning outcomes, increase

This research was funded by a U.S. Department of Agriculture Cooperative State Research, Education, and Extension Service Higher Education Challenge Grant. Indian River Research and Education Center Journal Series No. IRREC R-120602.

We gratefully acknowledge Marcela Pineros for DVD design and graphics; Lisa Hightower for videographing and transcribing; and Andrew Laing, David Heleba, and Wesley Wright for technical assistance.

${ }^{1}$ Natural Resources Division, Haywood Community College, 185 Freedlander Drive, Clyde, NC 28721

${ }^{2}$ Indian River Research and Education Center, University of Florida IFAS, 2199 South Rock Road, Fort Pierce, FL 34945

${ }^{3}$ Department of Agricultural and Biosystems Engineering, University of Arizona, Tucson, AZ 85721

${ }^{4}$ Department of Agricultural Education and Communication, University of Florida IFAS. P.O. Box 110540, Gainesville, FL 32611-0540

${ }^{5}$ Department of Horticulture and Crop Science, The Ohio State University, 248B Howlett Hall, 2001 Fyfee Court, Columbus, OH 43210

${ }^{6}$ Corresponding author. E-mail: sbwilson@ifas.ufl.edu. student enrollment, and foster better teachers (Mason, 2005). As society moves more toward worldwide webbased education or distant learning, plant scientists are using more creative lecture delivery methods.

For example, Wilson and Danielson (2005) created an interactive virtual plant identification and use instrument for a native landscaping course, in which students can walk virtually through a botanical garden and self-select plants to learn more about. Similarly, Wilson and Thetford (2003) animated the complete life cycle of an angiosperm for a webbased plant propagation course. Both of these projects were course-specific, but their applications are widespread.
There are nearly 30,000 acres of horticultural crops produced under protected environments in the United States (U.S. Dept. of Agriculture, 2002). More than 84 greenhouse-related courses are offered by instructors at land-grant institutions to teach greenhouse production and management concepts (Tignor et al., 2005). Nationwide, greenhouse industries are significantly diverse in terms of climate, systems, and crops, creating both educational challenges and opportunities to provide learning materials that share common conceptual issues of controlled plant environments (energy conservation, environmental safety, labor efficiency, plant response manipulation). Guzmán et al. (2005) developed a virtual laboratory for teaching greenhouse climatic control in which users have access to a full greenhouse climate model with specific control options. Faust (2005) developed greenhouse crop simulation software that allows the user to grow several crops online with different growing techniques, environments, and plant growth regulators. Evans et al. (2006) developed 15 virtual field trips that demonstrate various technologies and management strategies used in greenhouse management and controlled environment agriculture. Although these educational advancements are innovative and useful, their applications can be limited by crop specificity, complexity, or electronic accessibility and were not designed to consider geographic distinctions within the simulation model. The overall objective of this project was to develop a web-based multimedia instrument for greenhouse education to facilitate student learning and comprehension of greenhouse production and environmental control among diverse geographies, climates, and business practices. Specific objectives were to 1) produce greenhouse videos in Arizona, Vermont, Ohio, and Florida that emphasize state-specific

\begin{tabular}{llll}
\hline $\begin{array}{l}\text { Units } \\
\begin{array}{l}\text { To convert U.S. to SI, } \\
\text { multiply by }\end{array}\end{array}$ & U.S. unit & SI unit & $\begin{array}{l}\text { To convert SI to U.S., } \\
\text { multiply by }\end{array}$ \\
\hline 0.4047 & $\mathrm{acre}(\mathrm{s})$ & $\mathrm{ha}$ & 2.4711 \\
0.3048 & $\mathrm{ft}$ & $\mathrm{m}$ & 3.2808 \\
0.0929 & $\mathrm{ft}^{2}$ & $\mathrm{~m}^{2}$ & 10.7639 \\
0.4536 & $\mathrm{lb}$ & $\mathrm{kg}$ & 2.2046 \\
$\left({ }^{\circ} \mathrm{F}-32\right) \div 1.8$ & ${ }^{\circ} \mathrm{F}$ & ${ }^{\circ} \mathrm{C}$ & $\left(1.8 \times{ }^{\circ} \mathrm{C}\right)+32$
\end{tabular}


production, environmental control, labor, and marketing issues; 2) develop an interactive greenhouse environment simulator that allows users to model greenhouse environments based on climate data from each of the four video locations; 3 ) implement a searchable digital repository containing hundreds of useful greenhouse images, videos, and lectures; and 4) develop a web-based method for instructors to evaluate perceived student learning of greenhouse concepts.

\section{Greenhouse DVD}

In an effort to demonstrate varying greenhouse production practices among states, a video producer was contracted and sent to Vermont, Arizona, Ohio, and Florida for filming. All videos were recorded using a digital Sony PD-150 (Sony Corp., Tokyo) with similar subject content, shooting style, and interview length. Two to $3 \mathrm{~h}$ of original video at each location were edited using a Sony D-1000 deck and fire-wired into a G3 Mac computer using Final Cut Pro software (Apple Computer, Cupertino, Calif.). Videos from each location were organized by topic into 55 smaller 1 - to 8 -min segments, including introduction to the state industry, introduction to a specific business, greenhouse structure, sample crop cycle, crop nutrition, pest control practices, and computer use. These clips were created to be "standalone" and can be viewed on their own or compared and contrasted with each other. A DVD menu was designed to facilitate instructor and student access and use. Also, each video was transcribed so that the text can be viewed and printed. The DVD was engineered for a standalone player connected to a television or use in a computer. The video clips were also placed on a streaming server and archived in a digital repository, thus increasing user accessibility.

\section{Greenhouse environment simulator ('a plant's day in the life of a greenhouse')}

An interactive greenhouse environment simulator was developed by integrating mathematical models created for this application and an animation interface (Flash MX Pro 2004; Macromedia, San Francisco) for demonstrating environmental control principles with emphasis on cooling, heating, ventilation, and glazing materials. The greenhouse mathematical model, based on energy balance of the greenhouse component systems, is a set of differential equations that are solved numerically using the fourth-order Runge-Kutta (RK4) method (Chapra and Canale, 2002). The model was programmed using ActionScript 2.0 (Adobe Systems, San Jose, Calif.) and tied to the climate data from each location and the Flash graphic interface. The solution provides the dynamic response of the greenhouse moist air properties to outside climate conditions for a particular greenhouse design. A user can complete a range of simulations from a simple nonventilated greenhouse with no environmental control, demonstrating the true "greenhouse effect" to a greenhouse with ventilation, shadecloth, heating, and cooling set points. Multiple user-selected control options combine to provide a comparison of more than 32,000 possible design scenarios. Option selections include: geographic location (Arizona, Ohio, Florida, or Vermont), season (winter, spring, summer, or fall), structure type
(A-frame, arch, or Quonset), glazing (glass, polyethylene, or polycarbonate with single layer or double layer), ventilation (absent, natural, or forced at half or full capacity with the vented option), cooling (absent and wet pads at half or full capacity), heating (absent, half capacity, or full capacity), plant biomass/evapotranspiration (absent, small, or large), and set points for air temperature [no control or temperature set points (day $24^{\circ} \mathrm{C}$, night $18^{\circ} \mathrm{C}$ )]. After each design is created by the user, an internal environmental response is simulated by providing realistic graphics of a visual image of solar radiation, air temperature, and air humidity changes within the greenhouse in response to a $1-d$ cycle of external climate conditions (Fig. 1).

\section{Digital repository}

A web-based, searchable repository site was developed within DSpace (Massachusetts Institute of Technology and Hewlett-Packard Co., 2002) to house original greenhouse-related lectures, videos, and images from all over the world. Our DSpace site currently has 774 high-resolution greenhouse images

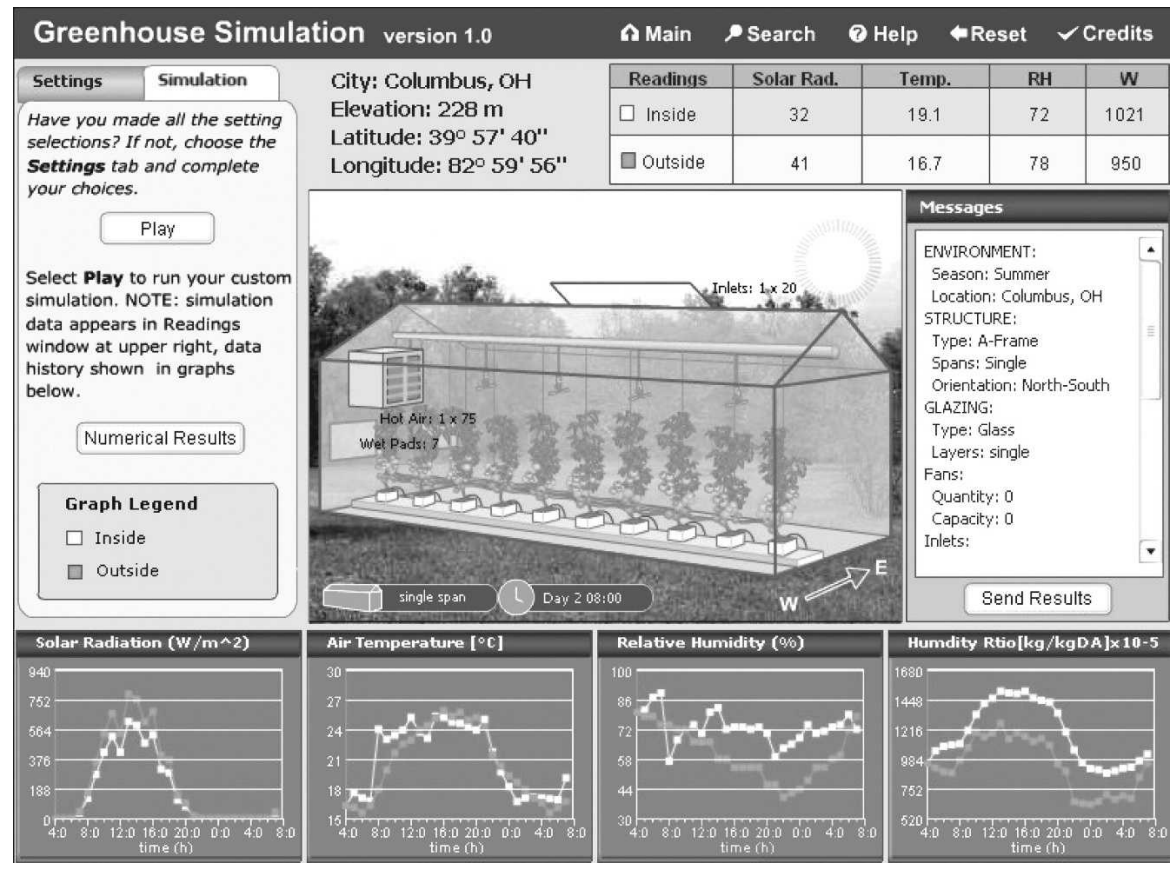

Fig. 1. Screen capture of a greenhouse simulation [with solar radiation (Solar Rad.), temperature (Temp.), and relative humidity ( $\mathrm{RH})$ outputs] after environment, structure, glazing, ventilation, and cooling options were selected (Tignor, 2005); $\mathrm{W}=$ watts, $\mathrm{W} / \mathrm{m}^{2}=\mathrm{W} \cdot \mathrm{m}^{-2}$, Rtio $=$ ratio, $\mathrm{kg} / \mathrm{kgDA}=\mathrm{kg} \cdot \mathrm{kg}^{-1}$ dry air, $1 \mathrm{~m}=$ $3.2808 \mathrm{ft}\left(1.8 \times{ }^{\circ} \mathrm{C}\right)+32={ }^{\circ} \mathrm{F}, 1 \mathrm{~m}^{2}=10.7639 \mathrm{ft}^{2}, 1 \mathrm{~kg}=2.2046 \mathrm{lb}$. 
(many with abstracts), six greenhouse design software packages of international and domestic origin (with tutorials), 11 lectures, and 65 videos. All of the materials have been granted educational distribution licenses by the authors or submitters. Since its inception 7 July 2004, the site has averaged 580 unique visits and 2650 bitstream views per month, thus illustrating interest in this web-based educational resource. Instructors who are interested in contributing to or accessing this database can e-mail the site administrator requesting full access. In addition to the digital repository, the entire greenhouse glossary within the Greenhouse Operation and Management textbook (Nelson, 2003) was electronically reproduced (with permission by Pearson Education, Upper Saddle River, N.J.). The glossary is hosted by pbwiki.com (Coceve, Hillsborough, Calif.) and consists of several hundred definitions that can easily be added to by other instructors.

\section{Instrument for assessing student learning}

Learning assessment tools were developed to be used in conjunction with the web-based materials to assess student proficiency and knowledge growth. Derived from the competency-based, behaviorally anchored instrument developed by Dooley and Linder (2002), the materials were used in five courses taught at the University of Vermont, University of Arizona, and The Ohio State University. Instructors asked students to electronically complete a pretest competency evaluation at the beginning of the course and a posttest the last week of the course. The tests included questions in which students were asked to assess their initial level of competency by a 7-point scale that ranged from $1=$ novice to $7=$ expert and then to supply a written verification narrative in the text box provided to explain why they chose to rate themselves at a particular level. For the posttest, students completed the same assessment and answered the open-ended question, "Where did your growth occur?" Competency subjects included greenhouse structures and glazing materials, greenhouse environment impacts on plant growth and development, integrated pest management, best management practices, plant life cycles, root substrates, plant nutrition, irrigation, packing and postharvest operations, and regional/national/international industry differences. Pretest and posttest versions of the instrument also included course expectancies, evaluation of the course, and demographics.

Results from each course indicated significant knowledge growth from pretests to posttests in all competency areas (data not presented), indicating that the educational greenhouse materials presented here are aiding in the knowledge and level of competencies gained by students. Furthermore, text-based verification narratives supported these findings in terms of recognition of knowledge and competencies gained as a result of taking each course. This illustrates the value and effectiveness of using multimedia instruments to teach greenhouse concepts in a virtual environment that can be readily accessed by students no matter where they may be. The entire web-based content of the project (including the videos, greenhouse simulator, and digital repository) is now available to the educational and scientific greenhouse community worldwide (Tignor, 2005). Also, for educational purposes, a professional-grade copy of the DVD (containing the greenhouse videos organized within a user-friendly template) may be obtained by contacting the corresponding author.

\section{Literature cited}

Chapra, S.C. and R.P. Canale. 2002. Numerical methods for engineers: With software and programming applications. 4th ed. McGraw-Hill, New York.

Dooley, K.E. and J.R. Linder. 2002 Competency-based behavioral anchors as authentication tools to document dis- tance education competencies. J. Agr. Educ. 43:24-35.

Evans, M.R., J.S. Kuehny, T. Cavins, R. Harkess, and L. Greer. 2006. Virtual field trips for improving undergraduate education in controlled environment agriculture. HortScience 41:919. (Abstr.).

Faust, J. 2005. Greenhouse crop simulation software. Ohio Florists Assn. Short Course Bul. July:32. (Abstr.).

Guzmán, J.L., M. Berenguel, F. Rodríguez, and S. Dormido. 2005. Web-based remote control laboratory using a greenhouse scale model. Comput. Appl. Eng. Educ. 13:111-124.

Mason, J. 2005. Applying technology to horticultural education. Acta Hort. 672:47-55.

Massachusetts Institute of Technology and Hewlett-Packard Co. 2002. DSpace for MIT faculty and students. 27 Nov. 2006. <https://dspace.mit.edu/>.

Nelson, P.V. 2003. Greenhouse operation and management. 6th ed. Pearson Education, Upper Saddle River, N.J.

Russell, T.L. 1999. The no significant difference phenomenon. International Distance Education Certification Ctr. Publishers, Montgomery, Ala.

Tignor, M.E. 2005. Worldwide greenhouse education. 27 Nov. 2006. <http:// www.uvm.edu/wge/education.htm>.

Tignor, M.E., S.B. Wilson, L. Hightower, E. Fitz, G.A. Giacomelli, C. Kubota, E. Rhoades, T.A. Irani, M.J. McMahon, A. Laing, D.A. Heleba, and S. Greenleaf. 2005. Integrating video, interactive animations, images, and assessment toward an expandable instructor resource for greenhouse education. HortScience 40:1044. (Abstr.).

U.S. Dept. of Agriculture. 2002. Census of agriculture-Geographic area series census. 22 Jan. 2007. <http://www.nass. usda.gov/Census/Create_Census_US.jsp>.

Wilson, S.B. and H.E. Danielson. 2005. Interactive virtual plant identification and use. HortTechnology 15:729-730.

Wilson, S.B. and M. Thetford. 2003. A new strategy for teaching plant propagation by distance education. HortTechnology 13:577-578. 